\title{
Anti-inflammatory effect of rebamipide on the ocular surface
}

\author{
Mayumi Ueta ${ }^{1 *}$, Chie Sotosono $^{2}$, Norihiko Yokoi ${ }^{2}$, Shigeru Kinoshita ${ }^{2}$ \\ From 9th Symposium of Experimental Rhinology and Immunology of the Nose (SERIN 2013) \\ Leuven, Belgium. 21-23 March 2013
}

\section{Purpose}

The eyedrop form of rebamipide was approved in Japan for use in the treatment of dry eye diseases, because it up-regulates mucin secretion and production. Others reported that rebamipide, a gastroprotective drug, could not only increase gastric mucus production but also suppressed gastric mucosal inflammation and that it was dominantly distributed in mucosal tissues. In this study we investigated whether rebamipide has anti- inflammatory effects in the ocular surface.

\section{Methods}

We used ELISA and quantitative RT-PCR assay to examine the effects of rebamipide on polyI:C-induced cytokine expression by primary human conjunctival epithelial cells. We studied the effects of rebamipide on ocular surface inflammation in our murine experimental allergic conjunctivitis (EAC) model. Moreover, we also observed their condition of allergic conjunctivitis when we treated the dry eye patients accompanied with allergic conjunctivitis using rebamipide.

\section{Results}

Rebamipide could suppress polyI:C-induced cytokine mRNA expression and the production of CXCL10, CXCL11, RANTES, MCP-1, and IL-6 in human conjunctival epithelial cells. The topical administration of rebamipide suppressed conjunctival allergic eosinophil infiltration in our EAC model. Furthermore, the allergic conjunctivitis which accompanied by dry eye patients treated with rebamipide tended to be better.

\section{Conclusions}

The topical application of rebamipide on the ocular surface might suppress ocular surface inflammation

${ }^{1}$ Doshisha University, Kyoto Prefectural University of Medicine, Uji, Japan

Full list of author information is available at the end of the article by suppressing the production of cytokines by ocular surface epithelial cells.

\section{Author details}

'Doshisha University, Kyoto Prefectural University of Medicine, Uji, Japan. ${ }^{2}$ Kyoto Prefectural University of Medicine, Ophthalmology, Kyoto, Japan.

Published: 16 July 2013

doi:10.1186/2045-7022-3-S2-P21

Cite this article as: Ueta et al: Anti-inflammatory effect of rebamipide on the ocular surface. Clinical and Translational Allergy 2013 3(Suppl 2): P21.
Submit your next manuscript to BioMed Central and take full advantage of:

- Convenient online submission

- Thorough peer review

- No space constraints or color figure charges

- Immediate publication on acceptance

- Inclusion in PubMed, CAS, Scopus and Google Scholar

- Research which is freely available for redistribution
() Biomed Central
() Biomed Central

(c) 2013 Ueta et al; licensee BioMed Central Ltd. This is an Open Access article distributed under the terms of the Creative Commons Attribution License (http://creativecommons.org/licenses/by/2.0), which permits unrestricted use, distribution, and reproduction in any medium, provided the original work is properly cited. 